\title{
THE CONCEPT OF DMAIC METHODOLOGY APPLICATION FOR DIAGNOSTICS OF POTENTIAL INCOMPATIBILITIES IN AERONAUTICAL DATA REQUEST PROCESS
}

\author{
Ewa DUDEK \\ Warsaw University of Technology, Faculty of Transport, edudek@wt.pw.edu.pl \\ Abstract \\ The article is a continuation of the Author's study on the ways to ensure the quality and safety of \\ aeronautical data and information in the entire process of those data and information creation, collection, \\ processing and publication. This time, however, the emphasis was placed on the possibility to use the \\ DMAIC methodology for diagnostics of potential incompatibilities in aeronautical data request process. At \\ the beginning the DMAIC methodology was presented and the aeronautical data and information, as well as \\ the aeronautical data chain, were described. The Author paid special attention to the data request process, as it \\ is considered to be the most critical chain's stage. The proceeding diagram for this process, based on valid \\ legal requirements, was elaborated and described. Then the concept of DMAIC methodology application was \\ presented together with the proposed changes in the mentioned proceeding diagram. Finally, regarding the \\ FMEA analysis, presented in one of the previous articles [19], the new values of FMEA rating scales for: \\ consequence of failure - variable S, likelihood of failure - variable R and the most important one - the ability \\ to the detect the problem - variable $\mathrm{W}$ were estimated. At the end, conclusions were drawn. The analysed
} issues will be subject of Author's further study.

Keywords: diagnostics, aeronautical data, DMAIC methodology, incompatibilities

\section{KONCEPCJA WYKORZYSTANIA METODYKI DMAIC DO DIAGNOSTYKI POTENCJALNYCH NIEZGODNOŚCI W PROCESIE ZAMAWIANIA DANYCH LOTNICZYCH}

Streszczenie

Artykuł stanowi kontynuację prac Autorki nad zagadnieniem zapewnienia jakości i bezpieczeństwa danych i informacji lotniczych w całym procesie ich tworzenia, gromadzenia, przetwarzania i publikacji. Tym razem jednak skoncentrowano się na możliwości wykorzystania metodyki DMAIC do diagnostyki potencjalnych niezgodności $\mathrm{w}$ procesie zamawiania danych lotniczych. Na początku krótko przedstawiono metodykę DMAIC oraz opisano dane i informacje lotnicze, jak również łańcuch danych lotniczych. Główny nacisk położono na proces zamawiania danych, jako iż właśnie ten etap łańcucha jest uważany za najbardziej krytyczny. Na bazie obowiązujących przepisów prawnych opracowano i opisano schemat postępowania dla wspomnianego procesu. Następnie przedstawiono koncepcję wykorzystania metodyki DMAIC wraz z proponowanymi zmianami do wspomnianego schematu postępowania. Na koniec, w odniesieniu do analizy FMEA, opisanej w jednym z poprzednich artykułów [19], wyznaczono nowe wartości ocenianych w FMEA kryteriów: konsekwencji wystąpienia niezgodności - zmienna $S$, prawdopodobieństwa wystąpienia niezgodności - zmienna $R$ oraz najważniejszego - poziomu wykrywalności niezgodności - zmienna $W$. Wyciągnięto wnioski. Zagadnienia te będą przedmiotem dalszych prac Autorki.

Słowa kluczowe: diagnostyka, dane lotnicze, metodyka DMAIC, niezgodności

\section{INTRODUCTION}

The problem of aeronautical data and information quality assurance appears in the Author's work not for the first time. Those data and information quality $[18,20]$ has a direct and significant impact on flight operations' safety and regularity as well as efficiency of Air Traffic Management (ATM), that is why the Author consequently develops the ways to improve their creation, collection, processing and publication processes. In previous works (e.g. [6-9, 15, 19]) the Author proposed a comprehensive and systematic approach to quality assurance at all stages of the aeronautical data and information chain. Implementation of Six-Sigma method [9], Shewhart control charts [7] and Failure modes and effects analysis (FMEA) analysis [19] was proposed. In [6] a potential data incompatibility, based on a specific case study, was described and in [15] air transport telematics systems were analysed. [19] contains the concept of potential incompatibilities' diagnostics in the entire aeronautical data and information chain, while its second stage - aeronautical data origination was analysed in [8]. This time, however, attention is 
paid to the data request process - the first stage of the aeronautical data and information chain, and the application of DMAIC (Define-MeasureAnalyse-Improve-Control) methodology for the diagnostics of potential data discrepancies is proposed.

\subsection{DMAIC methodology}

The acronym DMAIC stands for a principle of continuous improvement or is (in other words) a data-driven quality strategy for improving processes. It is a main fundamental and an integral part of various pro-quality methods, especially the Six-Sigma one, based on ISO 13053 standards [12, 13]. The acronym DMAIC hides five interconnected steps: Define, Measure, Analyse, Improve, Control. All of them are indispensable and must be done in order to ensure the best possible result. Moreover, the entire process should be repeated periodically considering changes over time.

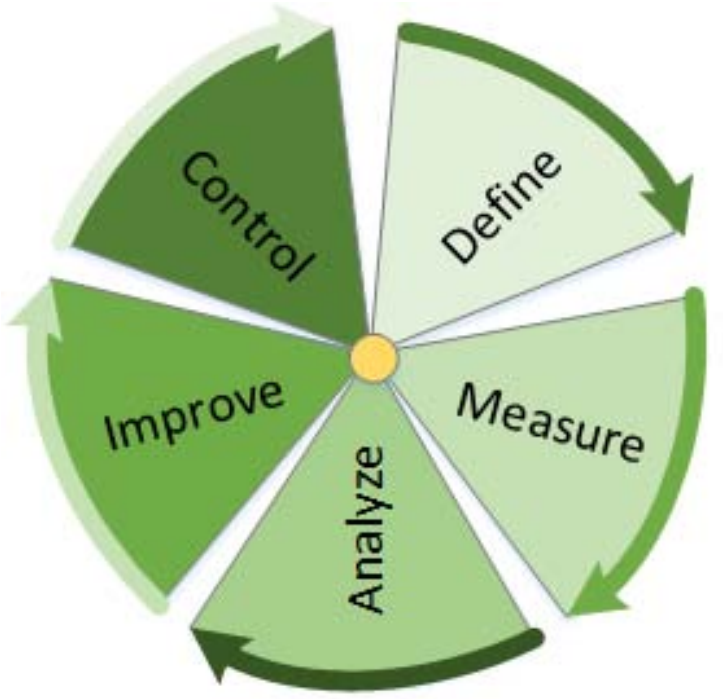

Fig. 1. Presentation of the DMAIC concept [own work]

Activities falling within the scope of each phase may be shortly described as:

- Define (D) - define the goal and the scope, requirements and expectations of the improvement, define issues critical to the analysed process' quality, define the process map and its connections;

- Measure (M) - measure process' performance, prepare a data collection plan and assemble the necessary data in accordance with the defined critical issues, determine the discrepancies;

- Analyse (A) - analyse the collected data and the determined process map, find the main reasons of incompatibilities as well as changes of the necessary improvements;

- Improve (I) - improve the process by removing the real causes of the problems thanks to trying out and implementation of the created solutions, take appropriate actions: improving, preventive or corrective to comply with the requirements;

- Control (C) - control/check whether the improvements implemented are adequate and sufficient, prevent reverting to old habits and ways of acting, update the documentation, personnel trainings as well as plan for the future.

\subsection{Aeronautical data and information}

Aeronautical data, according to [4] is a representation of aeronautical facts, concepts or instructions in a formalized manner suitable for communication, interpretation or processing. Aeronautical information at the same time is the information resulting from the assembly, analysis and formatting of aeronautical data [4]. To present a detailed explication it can be said that the term aeronautical data and information refers to [5]:

- the integrated aeronautical information package made available by Member States, with the exception of aeronautical information circulars,

- electronic obstacle data, or elements thereof, where made available by Member States,

- electronic terrain data, or elements thereof, where made available by Member States,

- aerodrome mapping data, where made available by Member States.

The analysed data and information life-cycle may be presented in an ordered manner, as the aeronautical data chain, which is a conceptual representation of the following stages of the mentioned data and information production, starting with data request and origination through to its operational use - figure 2.

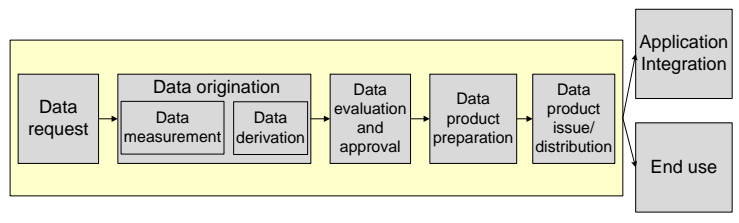

Fig. 2. Aeronautical data and information chain (own work based on [10])

Description of all the six following chain's stages may be found in [10] as well as in one of the Author's previous articles. In this paper the processes of data request are analysed.

\section{DATA REQUEST PROCESS}

Data request processes begin the activities in the aeronautical data chain. Based on the valid legal requirements this stage may be divided into three following parts:

- part 1: determination of data type and data quality requirements,

- part 2: selection of the unit responsible for data delivery, 
- $\quad$ part 3: data order from the selected provider.

It is especially important to properly identify user's as well as data quality requirements that are to be fulfilled in the following parts of the chain, as the quality of data created as their effect will strongly influence the overall quality of data used operationally. That is why this chain's stage is considered to be the most critical [10].

The proceeding diagram for the entire data request process is shown on figure 3 .

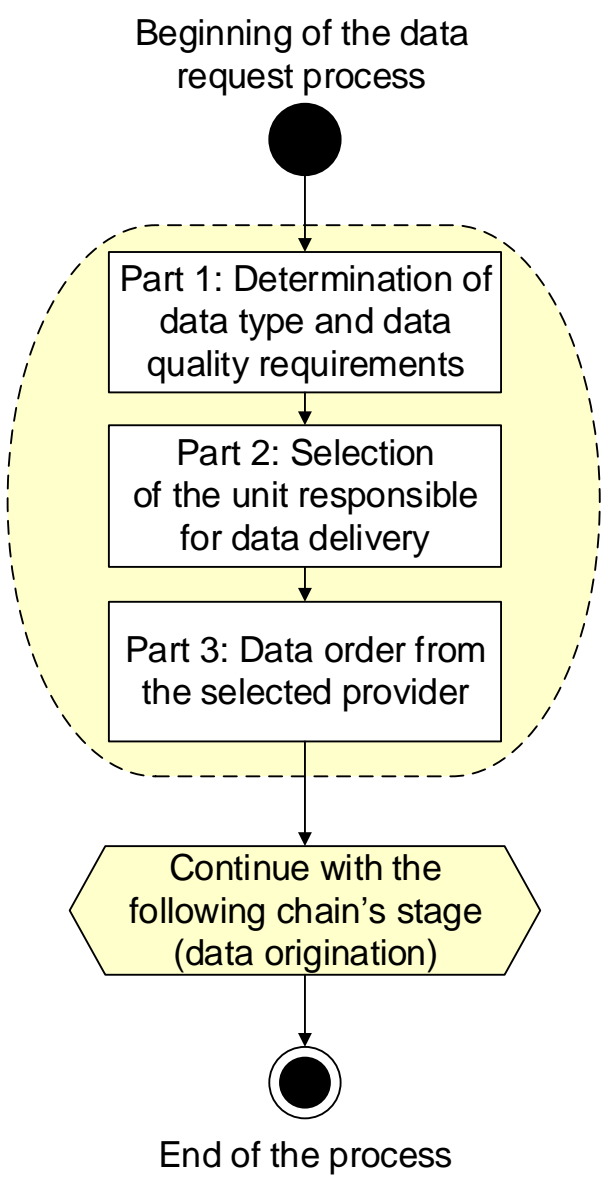

Fig. 3. Proceeding diagram for the data request stage [own work]

Based on the diagram presented on figure 3 it can be noted that not a single point of process'/mentioned parts' quality verification is included, although the presented procedure complies with the valid legal requirements as well as current practice. Which means that if the procedure is not complemented the evaluation will be delayed until the third data chains' stage. It also means that the diagnostics of potential incompatibilities is in practice impossible, as the conducted process is not evaluated. However, if the data request process quality is so important for the entire data chain (as stated in [10]), the Author asked herself a simple question - shouldn't the proceeding diagram be supplemented with evaluation activities after each distinguished part?

Lack of verification procedures impede the ability to detect incompatibilities or potential incompatibilities. Even simple non-compliances can be easily overlooked. Moreover, their late detection at the third data chain's stage (data evaluation and approval) does not give an answer to the question of their place of appearance. Therefore it is necessary to modify the presented proceeding diagram, to make the diagnostic of potential incompatibilities detection quicker and more precise with reference to their time and place of appearance.

The modified proceeding diagram for the data request stage, including application of the DMAIC methodology is shown on figure 4 .

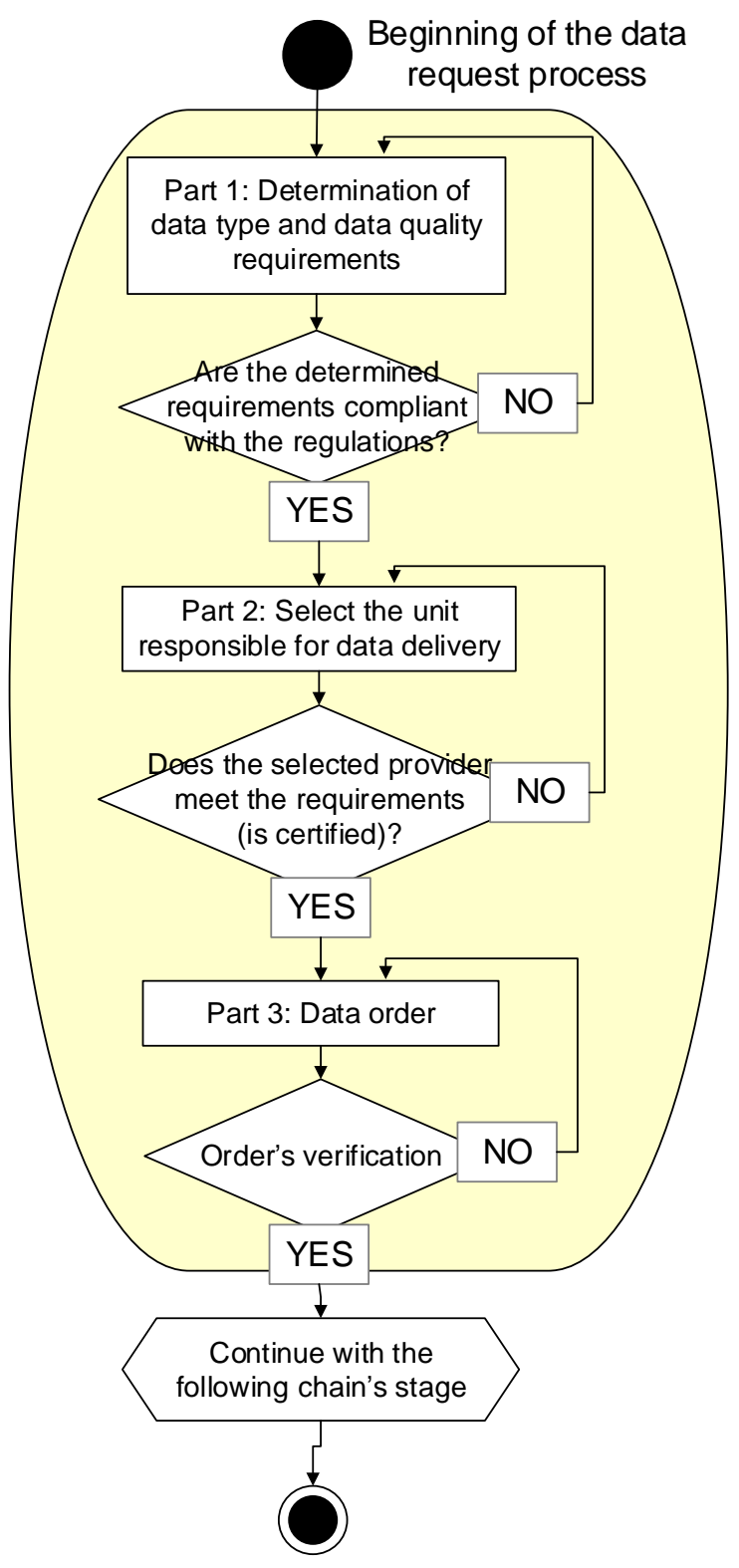

\section{End of the process}

Fig. 4. Modified proceeding diagram for the data request stage [own work]

In the solution presented on figure 4 it is proposed to implement the DMAIC analyse (A), improve (I) and control (C) phases after each distinguished data request process' parts, so that 
each part can be treated as a separate DMAIC cycle. The evaluation is then performed as phase evaluation and is carried out after conclusion of each part. Such approach facilitates potential incompatibilities disclosure, as their detection significantly increases.

Till now a similar analysis for the aeronautical data origination stage was conducted [8]. The scheme, used in practice, was analysed in details and modified by introducing into each step the verification and validation procedures, so that a potential or real incompatibility is diagnosed and identified up to date, and planning and implementation of preventive and correction actions occupies less time.

\section{FMEA ANALYSIS FOR THE DATA REQUEST PROCESS}

In one of the previous papers [19] the Authors used the FMEA method to conduct risk assessment analysis for the entire data chain. This was done in order to help detect possible incompatibilities and what may be even more important - diagnose the causes and effects of potential non-compliances.

The three basic parameters used in the Failure Mode and Effects Analysis were applied, identified and given a definite value:

- $\quad S$ - which stands for the consequences of failure,

- $\quad R$ - the likelihood of failure,

- $\quad W-$ the ability to detect the problem.

Their values were adopted according to the literature [e.g. 16] as well as ICAO Annexes 4 [1], 8 [2] and 13 [3] to the Convention on International Civil Aviation. Finally each of the parameters was assigned a value from 1 to 10 , based on the explanation presented in [19]. Their assessment allowed calculation of the Risk Priority Number $(R P N)[11,14]$ :

$$
R P N=S * R * W
$$

which is a measure of criticality obtained by multiplication of the numbers from the mentioned rating scales $-S, R, W$. The $R P N$ number takes the value from 1 to 1000 .

The results of the FMEA analysis for not modified proceeding diagram of the data request process, presented on figure 3 , are shown in table 2 .

According to criteria, described in table 1,

Table 1. Criteria for RPN interpretation (based on [16])

\begin{tabular}{|c|l|}
\hline RPN & \multicolumn{1}{|c|}{ Criteria } \\
\hline $1-99$ & $\begin{array}{l}\text { Incompatibility does not cause } \\
\text { a significant threat }\end{array}$ \\
\hline $100-1000$ & Incompatibility is a major threat \\
\hline
\end{tabular}

$R P N$ values smaller than 100 are marked with green colour (tables 1 and 2), while those equal to or greater than 100 are highlighted with red colour, as the ones which can cause a major safety threat.
From the point of view of the issues raised in this article, the most important value is the ability to diagnose the incompatibilities, represented by parameter $W$. It can be noted that $W$ values, presented in table 2, are big - close or equal to the maximum value. The reason for such assessment is that when no evaluation processes are conducted the diagnostics of potential incompatibilities is difficult or impossible as well as not effective.

Positive effects of the application of the solution presented on figure 4 can also be transferred to the FMEA analysis table. As soon as the evaluation in done after each executed stage the diagnostics of potential incompatibilities will be more effective and the $W$ parameter can be given a lower value.

These effects are shown in table 3.

\section{CONCLUSION}

The results of previous analysis of the entire data chain, presented among others in [19], showed that analysed aeronautical data and information process, considered within the scope of the methods and procedures determined in currently being in force specifications, may be unstable and often out of control, which means that in terms of incompatibility diagnostics it cannot be effectively and efficiently managed. This is important in terms of the Compliance Management System (CMS) implementation that was included in the Polish National Civil Aviation Safety Program [17].

At the same time the need to implement activities allowing minimization of likelihood of non-compliance appearance and increasing the chance of early (in fact uninterrupted and continuous) diagnostics of incompatibilities as well as taking the appropriate corrective actions was stated. One of the steps to achieve that goal is to implement modification to the presented proceeding diagram for the entire aeronautical data and information chain by implementing stage verification instead of the unitary one.

In this article the data request processes were analysed. The proceeding diagram for this process, based on valid legal requirements, was elaborated and described. Then the concept of DMAIC methodology application was presented together with the proposed changes in the mentioned proceeding diagram. Both diagrams were shown also in a schematic way. In order to confirm that the proposed solution gives expected results, the FMEA analysis was attached both for modified as well as unchanged procedures. The results for the solution with implemented modifications, represented in the FMEA analysis by the $R P N_{2}$ number, are 3 to 6 times lower than the $R P N_{l}$ ones. Moreover, the $R P N_{2}$ values are all within the safe range (from 1 to 99 ) and could be marked with green colour, and even more - the biggest obtained 

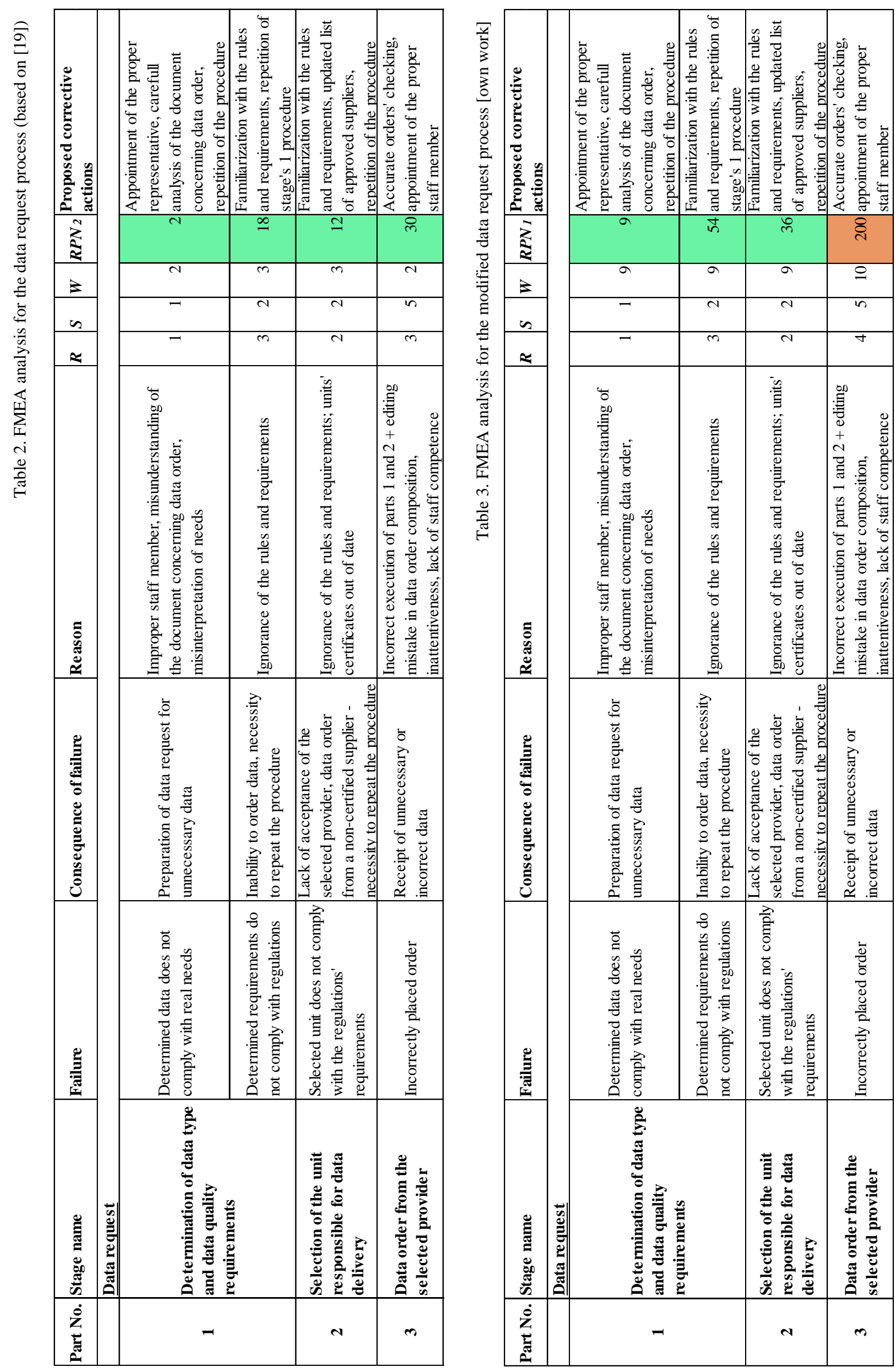
value is 30. Taking into account that $R P N$ may reach the value of a 1000 , the maximum result being 30 seems a perfect result.

From the six distinguished data chain stages till now only the first two were described and analysed. Implementation of a similar solutions is possible for the following ones as well. This will be subject of Author's further work.

\section{REFERENCES}

1. Annex 4 to the Convention on International Civil Aviation, Aeronautical Charts. 2009.

2. Annex 8 to the Convention on International Civil Aviation. Airworthiness of Aircraft. 2010.

3. Annex 13 to the Convention on International Civil Aviation, Aircraft Accident and Incident Investigation. 2010.

4. ICAO Annex 15 to the Convention on International Civil Aviation, Aeronautical Information Services, International Civil Aviation Organization, July 2013. Commission Regulation (EU) No 73/2010.

5. Dudek E, Kozłowski M. Analysis of aeronautical information potential incompatibility - case study. Journal of Konbin. 2017;41:59-82. https://doi.org/10.1515/jok-2017-0004

6. Dudek E, Kozłowski M. Koncepcja wykorzystania wybranej karty Shewharta do diagnostyki niezgodności mierzonych danych geoprzestrzennych. Pomiary Automatyka Robotyka, PIAP. 2017;3: 6974. https://doi.org/10.14313/PAR 225/69.

7. Dudek E, Kozłowski M. Koncepcja zastosowania metodyki DMAIC do zapewnienia jakości danych lotniczych, in: Kwasiborska A. (red.): Transport lotniczy i jego otoczenie. Wydział Transportu Politechniki Warszawskiej. 2016: 67-78.

8. Dudek E, Kozłowski M. The concept of a method ensuring aeronautical data quality. Journal of KONBiN. 2016;1(37): 319-340.

9. Eurocontrol Specification for Data Assurance Level, Reference nr: EUROCONTROL-SPEC-148, 2012.

10. IEC 60812:2006. Analysis techniques for system reliability, Part 2 Procedure for failure mode and effects analysis (FMEA). 2006.

11. ISO 13053-1:2011. Quantitative methods in process improvement - Six Sigma - Part 1: DMAIC methodology.

12. ISO 13053-2:2011. Quantitative methods in process improvement - Six Sigma - Part 2: Tools and techniques.

13. ISO 31010. Risk management - Risk assessment techniques. 2009.

14. Kozłowski M, Dudek E. Risk analysis in air transport telematics systems based on aircraft's Airbus A320 accident, in: Smart Solutions in Today's Transport / Mikulski Jerzy (red.). Communications in Computer and Information Science. 2017;715:385-395.

15. Myszewski J. Po prostu jakość: podręcznik zarządzania jakością. Wydawnictwa Akademickie i Profesjonalne. 2009.

16. Polish National Civil Aviation Safety Program, Civil Aviation Authority of the Republic of Poland. 2016.

17. Schroth Wolfgang R. Aeronautical Data Quality - A New Challenge for Surveyors; FIG Congress 2014 Engaging the Challenges - Enhancing the Relevance Kuala Lumpur. Malaysia 16 - 21 June 2014.
18. Siergiejczyk M, Kozłowski M, Dudek E. Diagnostics of potential incompatibilities in aeronautical data and information chain. Diagnostyka. 2017; 18(2): 87-93.

19. Wenguang X. Means for Avionics Manufacturers to Define the Aeronautical Data Quality Requirements, International Conference on Systems and Informatics. 2012: 2383-2387. https://doi.org/10.1109/ICSAI.2012.6223533

\section{Received 2018-05-14}

Accepted 2018-08-03

Available online 2018-09-04

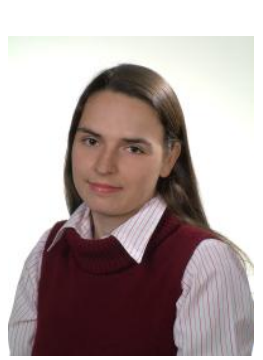

dr inż. Ewa DUDEK works in the Telecommunication Department at Warsaw University of Technology, Faculty of Transport. Scientific interests cover transport telematics, system integration, issues related to air traffic control as well as automation of continuous processes. 